\title{
URGING COTTON PLANTS TO OVERCOME THE SALT STRESS CONDITIONS IN THE RECLAIMED LAND USING A COMBINATION OF INNOVATIVE AGRICULTURAL FACTORS
}

(Received:15.3.2011)

\author{
By \\ M .D .H. Dewdar and M. M. Rady ${ }^{*}$ \\ Agronomy Department and ${ }^{*}$ Botany Department, \\ Faculty of Agriculture, Fayoum University
}

\begin{abstract}
The possibility of inducing cotton plants towards better growth and yielding under reclaimed soil with salinity level of about 7000 ppm was investigated in El-Tahrir Province, El-Behera Governorate, Egypt, during the two successive seasons of 2009 and 2010. For verifying this aim, the plants produced from calcium paste treated-seeds of cotton (seeds covered with the mixture of calcium nitrate, humic acid and wheat bran at the ratio of $1: 1: 3$, respectively by weight) were sprayed with ascorbic acid at the rates of 0 (control), 200, 400 and $600 \mathrm{mgL}^{-1}$. Significant positive influences of calcium paste applied solely or in combination with all ascorbic acid applications were observed on growth traits (number of leaf plant ${ }^{-1}$, total leaf area plant ${ }^{-1}$ and dry weight of leaf plant $^{-1}$ ), chemical constituents (photosynthetic pigments, some photosynthates, some macro-and micronutrients) and yield (seed cotton yield plant $^{-1}$ and feddan $^{-1}$ as well as lint\%) in comparison with the control (without calcium paste and ascorbic acid). As for ascorbic acid, plants sprayed with all studied rates represented significant increases in all aforementioned parameters with the best results obtained from the rate of $400 \mathrm{mgL}^{-1}$ as compared with untreated plants. Thereon, it has been recommended that spraying cotton plants (cultivar Giza 90), produced from calcium paste treated-seeds, with $400 \mathrm{mgL}^{-1}$ ascorbic acid solution may overcome the adverse conditions of reclaimed soils particularly, salinity up to $7000 \mathrm{ppm}$ and consequently, economic yield is obtainable.
\end{abstract}

Key words: ascorbic acid, cotton, reclaimed land, salinity, stress.

\section{INTRODUCTION}

Cotton (Gossypium barbadense L.) is one of the most important fiber crops in the world due to its properties and uses. In Egypt, it is well known that the cultivated area is continually on the decrease. Thus, experimental attempts of the enlargement in and/or render a judgement on cultivating cotton crop in success must be done in new reclaimed soils with some assistant factors beside, its cultivation in the old soils to face the world`s increasing demand of Egyptian cottons. It is worth mentioning that most of the new reclaimed areas in Egypt are salinity affected soils. Saline conditions disrupt several physiological processes in plants leading to a general reduction in growth and yield (Greenway and Munns, 1980, El-Saidi, 1997, Qadir and Shams 1997). The drastic influence of salinity on plant growth and metabolism was attributed, principally, to the enhanced $\mathrm{Na}^{+}$uptake which causes ion excess in plant tissues (Abbas et al.,
1991,Ella and Shlaby 1993 and Leidi and Saize 1997) beside, the inhibition of $\mathrm{K}^{+}, \mathrm{Ca}^{2+}$ and $\mathrm{NO}_{3}^{-}$ uptake by plant roots (Maas, 1986 and Gorham and Bridges 1997). In addition, it is well established that salinity stress damages plant cells through production of reactive oxygen species including superoxide, hydrogen peroxide, hydroxyl anions and singlet oxygen (Scandalios, 1997). Efforts have been made to control salinity by technological means; reclamation, drainage, use of high leaching fractions and application of soil amendments (Abdel-Naby et al., 2001). On the other hand, some trials have been made to alleviate the disturbances in plant metabolism excreted by salinity stress by using natural and safety substances among them ascorbic acid which may help to overcome some of these inhibitory effects (Rady and El-Sawah, 2009) beside, humic acids.

Ascorbic acid is an important antioxidant defense in plant cells (Foyer and Halliwell, 1976) 
to protect them by scavenging the reactive oxygen species. It also stimulates respiration activities, cell division and many enzyme activities (Rautenkranz et al., 1994). It has synergistic effects on growth, yield and its components as well as chemical composition of several crops under favorable and unfavorable environmental conditions i.e., salinity (Rady and El-Sawah, 2009). It has been proved that the application of humic acid, as an organic soil amendment used either individually or in combination with others, resulted in a significant increase in crop yield and its components in the sandy soils through its improving hydrophysical properties and nutrient availability (Osman and Ewees, 2008). Elevated $\mathrm{Ca}^{++}$concentrations in the nutrient solution mitigated the adverse effects of salinity by inhibition of $\mathrm{Na}^{+}$uptake (Greenway and Munns, 1980). LaHaye and Epstein (1969) clearly postulated that the $\mathrm{Ca}^{++} / \mathrm{Na}^{+}$interaction takes place at the plasma lemma. They suggested that $\mathrm{Na}^{+}$acted by displacing $\mathrm{Ca}^{++}$from membranes, leading to increased membrane permeability and intracellular $\mathrm{Na}^{+}$concentrations. After our preliminary pot studies, calcium nitrate, humic acid and wheat bran at the ratios of $1: 1: 3$ by weight, respectively as the components of calcium paste were found to be the most significant in ameliorating salinity effects on cotton plants at a level not more than $7000 \mathrm{ppm}$ (data not shown). Therefore, the mentioned components of calcium paste and the salinity level of $7000 \mathrm{ppm}$ were used in this study.

Accordingly, this work was planned for studying the influence of seed cotton application with calcium paste then, foliar application of the produced plants with ascorbic acid on growth, some chemical constituents and yield of cotton plants (cultivar Giza 90) grown under saline reclaimed soil conditions.

\section{MATERIALS AND METHODS}

During the two successive summer seasons of 2009 and 2010, a field trial was carried out at ElTahrir Province, El-Behera Governorate, Egypt, to realize the aforementioned aim. Before sowing, soil samples to $30 \mathrm{~cm}$ depth from the experimental site were collected and analyzed by the standard procedures of Jackson (1967). Analysis results of the soil samples are presented in Table (1).

Seeds of cotton (cultivar Giza 90) obtained from the Agricultural Research Center, Giza, Egypt were sown ( $20 \mathrm{~cm}$ between hills) on March 21, 2009 and 2010. Thinning was done 30 days after sowing leaving two plants hill ${ }^{-1}$. A seasonal total of 200, 250 and $100 \mathrm{~kg}$ feddan $^{-1}$ calcium superphosphate $\left(15.5 \% \quad \mathrm{P}_{2} \mathrm{O}_{5}\right)$, ammonium nitrate $(33.5 \% \mathrm{~N})$ and potassium sulphate $\left(48 \% \mathrm{~K}_{2} \mathrm{O}\right)$ were applied as recommended, respectively. treatments comprised 4 ascorbic acid rates; 0 (control), 200, 400 and $600 \mathrm{mgL}^{-1}$. These treatments were applied alone or in combination with seed treatment with calcium paste.

Table (1): Physical and chemical properties of the selected site in both seasons.

\begin{tabular}{|c|c|c|}
\hline Property & 2009 & 2010 \\
\hline \multicolumn{3}{|l|}{ Physical: } \\
\hline Clay\% & 24.70 & 23.50 \\
\hline Silt\% & 22.10 & 23.90 \\
\hline Sand $\%$ & 53.20 & 52.60 \\
\hline Soil texture & Loamy sand & Loamy sand \\
\hline \multicolumn{3}{|l|}{ Chemical: } \\
\hline $\mathrm{pH}(1: 2.5)$ & 7.900 & 7.750 \\
\hline $\mathrm{ECe}\left(\mathrm{dS} \mathrm{m} \mathrm{m}^{-1}\right)$ & 10.930 & 10.970 \\
\hline Organic matter\% & 1.080 & 1.100 \\
\hline $\mathrm{CaCO}_{3} \%$ & 6.050 & 6.090 \\
\hline Total N\% & 0.070 & 0.074 \\
\hline \multicolumn{3}{|c|}{ Available nutrients (mg Kg ${ }^{-1}$ soil): } \\
\hline $\mathrm{K}$ & 70.15 & 72.10 \\
\hline $\mathrm{P}$ & 19.05 & 18.80 \\
\hline $\mathrm{Fe}$ & 06.52 & 06.10 \\
\hline $\mathrm{Mn}$ & 05.45 & 05.00 \\
\hline $\mathrm{Zn}$ & 01.15 & 01.05 \\
\hline $\mathrm{Cu}$ & 01.60 & 01.75 \\
\hline
\end{tabular}

\subsection{Method of seed treatment with calcium paste}

\subsubsection{Preparation of calcium paste}

Calcium nitrate, humic acid and wheat bran (a by-product of wheat grain) at the ratio of 1:1:3 (by weight), respectively were mixed and kneaded together by using Arabic Gum solution (8\%) as a sticking agent to obtain paste of calcium able to remaining around seeds for a long time.

\subsubsection{Treatment of seeds with calcium paste}

Before sowing, cotton seeds were covered with calcium paste through the better mixing between them. Treated seeds were allowed to dry.

Chemical analysis of the most important components of humic acid and wheat bran was determined (Table 2) as outlined by A.O.A.C. (1995).

\subsection{Method of ascorbic acid application}

Ascorbic acid at the above mentioned concentrations was sprayed on the plant shoots to run off, three times; 40, 60 and 80 days after sowing. Few drops of Tween-20 were added to the spraying solution as a wetting agent.

The experimental design used was a split-plot with four replicates. The main plots were calcium paste treated-seeds or untreated seeds and ascorbic 
acid treatments occupied the sub-main plots. The Experimental unit was $21 \mathrm{~m}^{2}(3 \times 7 \mathrm{~m})$. The cultural practices were applied as recommended for cotton production except for the variables under study.

\subsection{Growth characters}

Three months after sowing, plants of four hills were randomly chosen from each experimental unit for determining the number of leaf plant ${ }^{-1}$, total leaf area plant ${ }^{-1}\left(\mathrm{dm}^{-2}\right)$ and dry weight of leaf plant $^{-1}(\mathrm{~g})$.

\subsection{Chemical constituents}

Leaf of the plants submitted to vegetative growth traits were also subjected to chemical. Chlorophyll a, chlorophyll $\mathrm{b}$ and total carotenoids were extracted by acetone (80\%) then, their concentrations were determined ( $\mathrm{mg} \mathrm{g}^{-1}$ fresh leaf) using colorimetric method as described by Arnon (1949). Ascorbic acid was determined ( $\mathrm{mg} \mathrm{g}^{-1}$ fresh leaf) using the dye 2,6-dichlorophenol indophenol method as outlined by A.O.A.C. (1995). Total soluble sugars were colorimetrically determined (mg $\mathrm{g}^{-1}$ dry matter) using phosphomolybdic acid reagent according to Dubois et al. (1956). Free proline was extracted by 5 -sulphosalicylic acid (3\%) then, determined ( $\mathrm{mg} \mathrm{g}^{-1}$ dry matter) colorimetrically using acid ninhydrin reagent as outlined by Bates et al. (1973). Nitrogen was colorimetrically determined ( $\mathrm{mg} \mathrm{g}^{-1}$ dry matter) by using the Orange $\mathrm{G}$ dye according to the method of Hafez and Mikkelsen (1981). For P, K, Ca, Na, Fe, Mn and $\mathrm{Zn}$ determinations; the wet digestion of $0.1 \mathrm{~g}$ of fine dry material of leaf of each treatment was done with sulphuric and perchloric acids mixture as mentioned by Piper (1947). Phosphorus (\%) were colorimetrically estimated using chlorostannus molybdo-phosphoric blue color method in sulphuric acid system as described by Jackson (1967). Potassium and sodium (\%) were determined using a Perkin-Elmer, Flame Photometer (Page et al., 1982). Calcium (\%), iron, manganese and zinc (ppm) were determined using a Perkin-Elmer, Model 3300, Atomic absorption Spectrophotometer (Chapman and Pratt, 1961).

\subsection{Seed cotton yield}

At harvest, plants of the four hills were randomly marked in each experimental unit to determine seed cotton yield hill ${ }^{-1}(\mathrm{~g})$ and lint percentage ( $\%$ of seed cotton). Seed cotton yield feddan $^{-1}$ (kentar) was determined using all plants of each experimental plot.

\subsection{Statistical analysis}

All data obtained in both seasons of this study were subjected to the analysis of variance. LSD at
0.05 was used to differentiate means according to Snedecor and Cochran (1980). Test of homogeneity, commonly known as the Bartlet's test was made according to Gomez and Gomez (1984).

\section{RESULTS AND DISCUSSION \\ 3.1. Growth characters}

Number of leaf plant ${ }^{-1}$, total leaf area plant $^{-1}$ and leaf dry weight plant ${ }^{-1}$ presented in Table (3) were significantly increased by 29.0, 36.2 and $29.4 \%$, respectively in the plants produced from seeds treated with calcium paste as compared with the parameters of the plants of the untreated seeds (combined data). These improving effects on studied parameters may be due to that $\mathrm{Ca}^{2+}$ of calcium paste reduced the harmful effects of salinity on seeds and consequently positively reflected on germination and emergence percentages. In addition, it has been explained in a way that root hairs of plants were able to maintain high levels of membrane-associated $\mathrm{Ca}^{2+}$ when exposed to high concentrations of $\mathrm{NaCl}$ (Cramer et al.,1985; Jafri and Ahmed 1995; Reinhardt and Roast 1995 a and b). In fact, it is essential to have $\mathrm{Ca}^{+}$of selective permeability i.e., membrane integrity (Poovaiah and Reddy, 1993). This helps in improving growth traits through improving plant growth. In addition, the mechanism of humic acid as one of calcium paste components on stimulating growth may be similar to that of plant growth regulators as humic substances function as auxins and thus affect plant metabolism in a positive manner (Osman and Ewees, 2008). Humic acid improves chemical properties of the soil because it increases soil microorganisms which enhance nutrient cycling positively reflecting on photosynthesis and growth (Sayed et al., 2007). It also promotes plant growth by its effects on ion transfer at the root level by activating the oxidation-reduction state of the plant growth medium and so increased absorption of nutrients especially, micronutrients by preventing precipitation in the nutrient solution. Furthermore, it enhances cell permeability, which in turn makes more rapid entry of nutrients into root cells and so results in higher uptake of plant nutrients. This effect was associated with the function of hydroxyls and carboxyls in these compounds (Osman and Ewees, 2008). Wheat bran as one of calcium paste components is able to maintain the water (Table 2) in rhizosphere and consequently dilution of salinity around the seeds. Regarding the results of this study, increasing macro-and microelements $(\mathrm{N}, \mathrm{P}, \mathrm{K}, \mathrm{Ca}, \mathrm{Fe}, \mathrm{Mn}$ 
and $\mathrm{Zn}$ ) as shown in Tables (6-8) and the decrease in $\mathrm{Na}^{+}$(Table 7) induced by seed treatment with calcium paste led to the significant increase in growth characters.

All sub-main treatments; ascorbic acid at the rates of $0,200,400$ and $600 \mathrm{mgL}^{-1}$ (Table 3) revealed a gradual significant increase in all studied vegetative growth traits, i.e., number of leaf plant $^{-1}$, total leaf area plant ${ }^{-1}$ and leaf dry weight plant $^{-1}$ which was observe as a result in raising ascorbic acid rate gradually applied up to $400 \mathrm{mgL}^{-1}$. The rate of $600 \mathrm{mgL}^{-1}$ ascorbic acid proved to slightly decrease the mentioned parameters as compared with the rate of 400 $\mathrm{mgL}^{-1}$. The maximum results were recorded with ascorbic acid foliar application at the rate 400 $\mathrm{mgl}^{-1}$. This rate surpassed the results of water foliar spray (the rate of zero $\mathrm{mL}^{-1}$ ascorbic acid) by $27.7,33.9$ and $27.6 \%$ for the number of leaf plant $^{-1}$, total leaf area plant ${ }^{-1}$ and leaf dry weight plant $^{-1}$, respectively (combined data). These results indicate that the most pronounced counteracted effects of the studied soil salinity $(\mathrm{Ca}$ $6000 \mathrm{ppm}$ ) on vegetative growth traits under study existed by the exogenous application of ascorbic acid which led to the increase in endogenous level of this substance (Table 5) and consequently protect plant cells including the photosynthetic apparatus by scavenging reactive oxygen species (Zhang and Schmidt, 2000) thus, vigorous plant growth will be obtained under salinity stress. In this connection, Elade (1992) stated a positive action for antioxidants especially, ascorbic acid on growth and attributed this finding to their effects on counteracting drought, salinity and disease stresses and protecting plant cells against free radicals responsible for plant senescence as well as to their auxinic action and consequently enhancing growth characters. In addition, ascorbic acid might regulates cell wall expansion, cell division and cell elongation through its action in cell vacuolarization (Cordoba-Pedregosa et al., 1996), improves the nutritional status (Tables 6-8) and absorbing phenolic compounds which lead to save the growing tissues from toxic effects of the oxidized phenols (Gupta et al., 1980) and/or enhances the biosynthesis of soluble sugars (Table 5). These findings are in coincidence with those obtained by Ahmed et al. (1998); Rady and ElSawah (2009).

The effect of the interactions between the main treatments (untreated or treated seeds with calcium paste) and the sub-main treatments (ascorbic acid foliar application) was significant. The highest values of the number of leaf plant ${ }^{-1}$, total leaf area plant ${ }^{-1}$ and leaf dry weight plant $^{-1}$ were recorded from the treatment of $400 \mathrm{mgL}^{-1}$ ascorbic acid under seed treatment with calcium paste which recorded 21.4, 29.2 and $24.0 \%$ increases, respectively as compared to the treatment of zero $\mathrm{mgL}^{-1}$ ascorbic acid under seed treatment with calcium paste and recorded 70.1, 87.5 and $69.1 \%$ increases, respectively above the treatment of zero $\mathrm{mgL}^{-1}$ ascorbic acid under untreated seeds (combined data). The superiority of the treatment having the highest values might come from improving the nutritional status of the plants of this treatment (Tables 6-8), the shortage of $\mathrm{Na}^{+}$(Table 7) and the increase in total soluble sugars and free proline (Table 5) saving more osmotic solutes which enable plant cells to maintain more water against salinity.

\subsection{Chemical constituents}

3.2.1. Leaf photosynthetic pigments, soluble sugars, free proline and ascorbic acid

Results in Tables (4 and 5) reveal that chlorophyll a, chlorophyll b, total carotenoids, total soluble sugars, free proline and ascorbic acid in plant leaf were significantly increased by 29.8 , $32.1,30.6,19.4,23.6$ and $19.3 \%$, respectively as a result of treating the seeds with calcium paste as compared with the untreated seeds (combined data). These pronounced increments may be due to the increase in ascorbic acid in plant leaf (Table 5) which had an auxinic actions and also synergistic effects on biosynthesis of sugars and carbohydrates (Al-Qubaie, 2002). Besides, the effective role of $\mathrm{Ca}^{++}$and wheat bran in $\mathrm{Na}^{+}$ driving away and more water retention around seeds, respectively. In addition, humic acid (as one of the calcium paste components) enhanced the chlorophyll content reflecting from its role in enhancing leaf nutritional status (Tables 6-8) especially, $\mathrm{N}$ as an important part of chlorophyll molecule. Moreover, humic acids led to uptake K element leading to a corresponding increase in the chlorophyll fluorescence which can serve as an indicator of stress induced accompanied with alteration of the endogenous hormone balance (Marschner, 1995).

Our results indicated that chlorophyll a, chlorophyll b, total carotenoids, total soluble sugars, free proline and ascorbic acid concentrations in plant leaf, were gradually increased by significant quantities as a result of foliar application with ascorbic acid up to 400 $\mathrm{mgL}^{-1}$ then neglictably decreased (combined data, tables 4 and 5). The previous characters were increased by $23.5,26.327 .8,31.3,28.3$ and $26.3 \%$,respectively with spraying ascorbic acid at 
Table (2): The most important constituents of humic acid and wheat bran used in the experiment of both seasons.

\begin{tabular}{|l|c|c|l|c|c|}
\hline \multicolumn{2}{|c|}{ Humic acid analysis } & \multicolumn{2}{c|}{ Wheat bran analysis } \\
\hline Main constituent & 2009 & 2010 & Main constituent & 2009 & 2010 \\
\hline Humic acid\% & 18.5 & 18.5 & Moisture\% & 4.50 & 4.30 \\
\hline Total Fe\% & 0.5 & 0.5 & Ash\% & 5.20 & 5.15 \\
\hline Total Mn\% & 0.5 & 0.5 & Total fibers\% & 35.45 & 36.25 \\
\hline Total Zn\% & 0.5 & 0.5 & Water holding & \multirow{2}{*}{3.35} & \multirow{2}{*}{3.40} \\
\hline Total Cu\% & 0.5 & 0.5 & capacity $\left(\mathrm{g} \mathrm{g}^{-1}\right)$ & \\
\hline
\end{tabular}

Table (3): Influence of calcium paste and ascorbic acid on some growth traits of cotton plants under saline reclaimed soil conditions (Data are combined across seasons).

\begin{tabular}{|c|c|c|c|c|c|c|c|c|c|}
\hline \multirow{2}{*}{$\begin{array}{l}\text { Ascorbic acid } \\
\quad\left(\mathrm{mgL}^{-1}\right)\end{array}$} & $0 \mathrm{Ca}^{+2}$ & $\stackrel{+}{\mathrm{Ca}^{+2}}$ & $\begin{array}{c}\text { Mean } \\
\text { B }\end{array}$ & $0 \mathrm{Ca}^{+2}$ & $\stackrel{+}{\mathrm{Ca}^{+2}}$ & $\begin{array}{c}\text { Mean } \\
\text { B }\end{array}$ & $0 \mathrm{Ca}^{+2}$ & $+\mathrm{Ca}^{+2}$ & $\begin{array}{c}\text { Mean } \\
\text { B }\end{array}$ \\
\hline & \multicolumn{3}{|c|}{ Number of leaves plant ${ }^{-1}$} & \multicolumn{3}{|c|}{$\begin{array}{l}\text { Total leaves area plant } \\
\left(\mathrm{dm}^{2}\right)\end{array}$} & \multicolumn{3}{|c|}{$\begin{array}{l}\text { Dry weight of leaves plant } \\
{ }_{1}^{1}(\mathrm{~g})\end{array}$} \\
\hline 0 & 27.4 & 38.4 & 32.9 & 33.7 & 48.9 & 41.3 & 16.2 & 22.1 & 19.2 \\
\hline 200 & 32.2 & 41.9 & 37.1 & 39.9 & 55.2 & 47.6 & 18.9 & 24.2 & 21.6 \\
\hline 400 & 37.3 & 46.6 & 42.0 & 47.3 & 63.2 & 55.3 & 21.5 & 27.4 & 24.5 \\
\hline 600 & 37.0 & 45.8 & 41.4 & 45.9 & 60.0 & 53.0 & 20.9 & 26.8 & 23.9 \\
\hline Mean A & 33.5 & 43.2 & & 41.7 & 56.8 & & 19.4 & 25.1 & \\
\hline $\begin{array}{rr}\mathbf{L S D}_{0.05} & \mathbf{A} \\
\mathbf{B} \\
\mathbf{A} \times \mathbf{B}\end{array}$ & & $\begin{array}{l}3.6 \\
2.5 \\
5.6\end{array}$ & & & $\begin{array}{l}4.7 \\
3.4 \\
6.7\end{array}$ & & & $\begin{array}{l}2.7 \\
1.8 \\
3.9\end{array}$ & \\
\hline
\end{tabular}

$+\mathrm{Ca}=$ Seed covered with calcium paste (Calcium nitrate: Humic acid: Wheat bran 1:1:3 by weight).

$\mathrm{0Ca}=$ Seed without calcium paste.

A denotes Ca treatments, $B$ denotes ascorbic acid treatments and $A \times B$ denotes the interaction.

Table (4): Influence of calcium paste and ascorbic acid on leaf photosynthetic pigments of cotton plants under saline reclaimed soil conditions (Data are combined across seasons).

\begin{tabular}{|c|c|c|c|c|c|c|c|c|c|}
\hline \multirow{2}{*}{$\begin{array}{l}\text { Ascorbic acid } \\
\quad(\text { mgL-1) }\end{array}$} & $\begin{array}{c}0 \\
\mathrm{Ca}+2\end{array}$ & $\begin{array}{c}+ \\
\mathbf{C a}+2\end{array}$ & $\begin{array}{c}\text { Mean } \\
\text { B }\end{array}$ & $\begin{array}{c}0 \\
\mathrm{Ca}+2\end{array}$ & $\begin{array}{c}+ \\
\mathbf{C a}+2\end{array}$ & $\begin{array}{c}\text { Mean } \\
\text { B }\end{array}$ & $\begin{array}{c}0 \\
\mathrm{Ca}+2\end{array}$ & $\begin{array}{c}+ \\
\mathbf{C a}+2\end{array}$ & $\begin{array}{c}\text { Mean } \\
\text { B }\end{array}$ \\
\hline & \multicolumn{3}{|c|}{$\begin{array}{c}\text { Chlorophyll a } \\
\text { (mg g-1 fresh weight) }\end{array}$} & \multicolumn{3}{|c|}{$\begin{array}{c}\text { Chlorophyll b } \\
\text { (mg g-1 fresh weight) }\end{array}$} & \multicolumn{3}{|c|}{$\begin{array}{c}\text { Total carotenoids } \\
\text { (mg g-1 fresh weight) }\end{array}$} \\
\hline 0 & 0.73 & 0.96 & $\mathbf{0 . 8 5}$ & 0.48 & 0.66 & $\mathbf{0 . 5 7}$ & 0.31 & 0.41 & $\mathbf{0 . 3 6}$ \\
\hline 200 & 0.81 & 1.05 & 0.93 & $\mathbf{0 . 5 3}$ & 0.72 & 0.63 & 0.34 & 0.45 & 0.40 \\
\hline 400 & 0.91 & 1.19 & 1.05 & 0.63 & 0.81 & 0.72 & 0.40 & 0.51 & 0.46 \\
\hline 600 & 0.89 & 1.15 & 1.02 & 0.61 & 0.77 & 0.69 & 0.39 & 0.50 & 0.45 \\
\hline Mean A & 0.84 & 1.09 & & 0.56 & 0.74 & & 0.36 & 0.47 & \\
\hline $\begin{array}{r}\text { LSD0.05 } \underset{\mathbf{B}}{\mathbf{A}} \\
\mathbf{A} \times \mathbf{B}\end{array}$ & & $\begin{array}{l}0.11 \\
0.08 \\
0.17\end{array}$ & & & $\begin{array}{l}0.07 \\
0.05 \\
0.10\end{array}$ & & & $\begin{array}{l}0.05 \\
0.03 \\
0.08\end{array}$ & \\
\hline
\end{tabular}


the rate of $400 \mathrm{mgL}^{-1}$ as compared with the treatment free from ascorbic acid (tap water). The promotive effect of ascorbic acid on chlorophylls and carotenoids and the other components under study might be attributed to the enhancing effects of this antioxidant on the nutritional status of cotton plants (Tables 6-8). $\mathrm{N}$ is one of the essential chlorophyll components. Besides, $\mathrm{Fe}$ and $\mathrm{Mn}$ are necessary for the biosynthesis of chlorophyll and $\mathrm{Zn}$ is necessary for the biosynthesis of tryptophan which is the precursor of auxin biosynthesis and consequently more biosynthesis of these components in the face of cell elongation. Furthermore, the role of ascorbic acid as an antioxidant, directly involved in the regulation and protection of photosynthetic processes (Farago and Brunhold, 1994) could lead to the enhancing effect on pigments and the components under study. This treatment having the highest values of the constituents under study bestowed the tested plants the ability to satisfactorily overcome soil salinity. This may be due to their containing sufficient amount of soluble sugars, free proline (Table 5) which form sufficient cellular solutes able to sustain of cell turgor. This, maintains metabolic activities in the plant cells and/or protect plants against adverse conditions i.e. salinity and drought. The enhancing effect of ascorbic acid on tested soluble sugars might be attributed to its promotive effect on studied pigments (Table 4) leading to the enhancement of photosynthesis and consequently, the increase in the photosynthates. The positive effects of ascorbic acid on pigments and photosynthates obtained in this study are in agreement with those obtained by Rady and ElSawah (2009).

The results of the combination between treated or untreated seeds with calcium paste and ascorbic acid foliar application exhibited in Tables (4 and 5) revealed that the combination between calcium paste treated-seeds and spraying plant shoots with ascorbic acid at $400 \mathrm{mgL}^{-1}$ increased chlorophyll $\mathrm{a}$, chlorophyll $\mathrm{b}$, total carotenoids, total soluble sugars, free proline and ascorbic acid by 24.0 , $22.7,24.4,29.5,27.1$ and $28.0 \%$, respectively as compared to calcium paste treated-seeds interacted with foliar spray with tap water, and by $63.0,68.8$, 64.5, 59.7, 59.6 and 52.2\% when compared with the combined treatment of zero rate ascorbic acid under calcium paste untreated-seeds it scored increments, respectively. These significant increases scored as a result of the application with $\mathrm{Ca}^{++}$, wheat bran as a fibrous source having high water holding capacity and ascorbic acid. The former may reduce the harmful effects of salinity by its taking the place of $\mathrm{Na}^{+}$in rhizosphere and may on membranes in absorbing roots. The second; wheat bran saves more water to overcome drought caused by salinity in the soil. The latter; ascorbic acid as one of antioxidants prevent enzyme inactivation, prevent the generation of more dangerous radicals and allow flexibility in the production of photosynthetic assimilatory power. Moreover, electron transfer to $\mathrm{O}_{2}$ prevented over reduction of electron transports chain, which reduced the risk of harmful back reaction within the photosystem (Foyer et al., 1990). In addition, Elade (1992) proved that most antioxidants were responsible for accelerating the biosynthesis of various pigments and consequently more photosynthesis producing more quantities of photosynthates. Besides, Shahidi and Wanasundara (1992) stated that, phenolic antioxidants play important roles as free radical terminators and sometimes, as a metal chelators.

\subsubsection{Macro-and micronutrients}

It could be stated from the combined data in Tables (6-8) that $\mathrm{N}, \mathrm{P}, \mathrm{K}, \mathrm{Ca}, \mathrm{Ca} / \mathrm{Na}$ ratio, $\mathrm{Fe}, \mathrm{Mn}$ and $\mathrm{Zn}$ were significantly increased with the treatment of calcium paste covered-seeds as compared with the treatment of calcium paste untreted-seeds. These increases were 23.4, 40.0, 25.7, 22.8, 82.9, 13.5, 10.8 and $14.0 \%$ for N, P, K, $\mathrm{Ca}, \mathrm{Ca} / \mathrm{Na}$ ratio, $\mathrm{Fe}, \mathrm{Mn}$ and $\mathrm{Zn}$, respectively. On the other side, Na showed a reversed behavior. It decreased with increasing other elements at $34.7 \%$ in plant leaf. The shortage occurred in $\mathrm{Na}^{+}$and the increase in $\mathrm{Ca}^{++}$; the increase in $\mathrm{Ca} / \mathrm{Na}$. In addtion, the high water retention capacity of wheat bran (Table 2) and having some minerals such as $\mathrm{Fe}, \mathrm{Mn}, \mathrm{Zn}$ and $\mathrm{Cu}$ of humic acid (Table 2) might explain these results. Humic acid as one of the calcium paste components plays an important role for increasing the supplying power of soil capacity against nutrient loss and deficiency. The principal physiological function of humic acids may be that they reduce oxygen deficiency in plants, which results in better uptake of nutrients (Osman and Ewees, 2008).

The data presented in Tables (6-8) reveal that when Na significantly reduced, all tested nutrients represented significant gradual increases with increasing ascorbic acid rate. Spraying of ascorbic acid at the rate of $400 \mathrm{mgL}^{-1}$ proved to be the best and exhibited, in general, the most pronounced counteracted effect on soil salinity. The treatment of $400 \mathrm{mg} \mathrm{L}^{-1}$ ascorbic acid surpassed the treatment of tap water by 19.1, 36.7, 21.4, 25.3, 
Table (5): Influence of calcium paste and ascorbic acid on some leaf photosynthates of cotton plants under saline reclaimed soil conditions (Data are combined across seasons).

\begin{tabular}{|c|c|c|c|c|c|c|c|c|c|}
\hline \multirow{2}{*}{$\begin{array}{l}\text { Ascorbic acid } \\
\quad(\text { mgL-1) }\end{array}$} & $\begin{array}{c}\mathbf{0} \\
\mathrm{Ca}+2\end{array}$ & $\begin{array}{c}+ \\
\mathbf{C a}+2 \\
\end{array}$ & $\begin{array}{c}\text { Mean } \\
\text { B }\end{array}$ & $\begin{array}{c}0 \\
\mathrm{Ca}+2\end{array}$ & $\begin{array}{c}+ \\
\mathrm{Ca}+2\end{array}$ & $\begin{array}{c}\text { Mean } \\
\text { B }\end{array}$ & $\begin{array}{c}0 \\
\mathrm{Ca}+2 \\
\end{array}$ & $\begin{array}{c}+ \\
\mathrm{Ca}+2 \\
\end{array}$ & $\begin{array}{c}\text { Mean } \\
\text { B }\end{array}$ \\
\hline & \multicolumn{3}{|c|}{$\begin{array}{c}\text { Total soluble sugars (mg } \\
\text { g-1 dry weight) }\end{array}$} & \multicolumn{3}{|c|}{$\begin{array}{c}\text { Free proline } \\
\text { (mg g-1 dry weight) }\end{array}$} & \multicolumn{3}{|c|}{$\begin{array}{c}\text { Ascorbic acid } \\
\text { (mg g-1 fresh weight) }\end{array}$} \\
\hline $\mathbf{0}$ & 20.6 & 25.4 & 23.0 & 0.47 & 0.59 & 0.53 & 0.69 & 0.82 & 0.76 \\
\hline 200 & 23.8 & 28.1 & 26.0 & 0.53 & 0.67 & 0.60 & 0.78 & 0.92 & 0.85 \\
\hline 400 & 27.5 & 32.9 & 30.2 & 0.60 & 0.75 & 0.68 & 0.87 & 1.05 & 0.96 \\
\hline 600 & 27.0 & 31.5 & 29.3 & 0.58 & 0.71 & 0.65 & 0.97 & 1.18 & 1.08 \\
\hline Mean A & 24.7 & 29.5 & & 0.55 & 0.68 & & 0.83 & 0.99 & \\
\hline $\begin{array}{r}\text { LSD0.05 } \underset{A}{\mathbf{A}} \\
\mathbf{A} \times \mathbf{B}\end{array}$ & & $\begin{array}{l}3.3 \\
2.2 \\
4.8\end{array}$ & & & $\begin{array}{l}0.08 \\
0.06 \\
0.11\end{array}$ & & & $\begin{array}{l}0.10 \\
0.07 \\
0.14\end{array}$ & \\
\hline
\end{tabular}

Table (6): Influence of calcium paste and ascorbic acid on some macronutrients of cotton leaves under saline reclaimed soil conditions (Data are combined across seasons).

\begin{tabular}{|c|c|c|c|c|c|c|c|c|c|}
\hline \multirow{2}{*}{$\begin{array}{l}\text { Ascorbic acid } \\
\quad\left(\mathrm{mgL}^{-1}\right)\end{array}$} & $\mathrm{O} \mathrm{Ca}^{+2}$ & $+\mathrm{Ca}^{+2}$ & Mean B & $0 \mathrm{Ca}^{+2}$ & $+\mathrm{Ca}^{+2}$ & Mean B & $0 \mathrm{Ca}^{+2}$ & $+\mathrm{Ca}^{+2}$ & Mean B \\
\hline & \multicolumn{3}{|c|}{$\begin{array}{c}\text { Nitrogen } \\
(\% \text { dry weight }) \\
\end{array}$} & \multicolumn{3}{|c|}{$\begin{array}{l}\text { Phosphorus } \\
(\% \text { dry weight })\end{array}$} & \multicolumn{3}{|c|}{$\begin{array}{c}\text { Potassium } \\
(\% \text { dry weight })\end{array}$} \\
\hline $\mathbf{0}$ & 1.88 & 2.42 & 2.15 & 0.24 & 0.36 & 0.30 & 1.88 & 2.41 & 2.15 \\
\hline 200 & 2.06 & 2.58 & 2.32 & 0.29 & 0.41 & 0.35 & 2.08 & 2.61 & 2.35 \\
\hline 400 & 2.31 & 2.80 & 2.56 & 0.34 & 0.47 & 0.41 & 2.32 & 2.89 & 2.61 \\
\hline 600 & 2.29 & 2.74 & 2.52 & 0.32 & 0.44 & 0.38 & 2.27 & 2.83 & 2.55 \\
\hline Mean A & 2.14 & 2.64 & & 0.30 & 0.42 & & 2.14 & 2.69 & \\
\hline 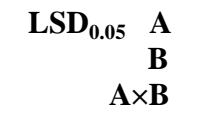 & & $\begin{array}{l}0.23 \\
0.15 \\
0.34\end{array}$ & & & $\begin{array}{l}0.05 \\
0.04 \\
0.07\end{array}$ & & & $\begin{array}{l}0.23 \\
0.16 \\
0.32\end{array}$ & \\
\hline
\end{tabular}

Table (7): Influence of calcium paste and ascorbic acid on calcium, sodium an $\mathrm{Ca} / \mathrm{Na}$ ratio of cotton leaves under saline reclaimed soil conditions (Data are combined across seasons).

\begin{tabular}{|c|c|c|c|c|c|c|c|c|c|}
\hline \multirow[b]{2}{*}{$\begin{array}{l}\text { Ascorbic acid } \\
\quad\left(\mathrm{mgL}^{-1}\right)\end{array}$} & $0 \mathrm{Ca}^{+2}$ & $+\mathrm{Ca}^{+2}$ & Mean B & $0 \mathrm{Ca}^{+2}$ & $+\mathrm{Ca}^{+2}$ & Mean B & $0 \mathrm{Ca}^{+2}$ & $+\mathrm{Ca}^{+2}$ & Mean B \\
\hline & \multicolumn{3}{|c|}{$\begin{array}{c}\text { Calcium } \\
(\% \text { dry weight })\end{array}$} & \multicolumn{3}{|c|}{$\begin{array}{c}\text { Sodium } \\
(\% \text { dry weight })\end{array}$} & \multicolumn{3}{|c|}{ Calcium/Sodium ratio } \\
\hline 0 & 0.90 & 1.07 & 0.99 & 1.20 & 0.70 & 0.95 & 0.75 & 1.53 & 1.14 \\
\hline 200 & 0.96 & 1.20 & 1.08 & 0.99 & 0.63 & 0.81 & 0.97 & 1.90 & 1.44 \\
\hline 400 & 1.10 & 1.37 & 1.24 & 0.79 & 0.56 & 0.68 & 1.40 & 2.46 & 1.93 \\
\hline 600 & 1.09 & 1.31 & 1.20 & 0.82 & 0.59 & 0.71 & 1.33 & 2.22 & 1.78 \\
\hline Mean A & 1.01 & 1.24 & & 0.95 & 0.62 & & 1.11 & 2.03 & \\
\hline $\begin{array}{r}\mathbf{L S D}_{0.05} \\
\mathbf{A} \\
\mathbf{A} \times \mathbf{B}\end{array}$ & & $\begin{array}{l}0.13 \\
0.08 \\
0.20\end{array}$ & & & $\begin{array}{l}0.09 \\
0.06 \\
0.12\end{array}$ & & & $\begin{array}{l}0.16 \\
0.11 \\
0.23\end{array}$ & \\
\hline
\end{tabular}


Table (8): Influence of calcium paste and ascorbic acid on some micronutrients of cotton leaves under saline reclaimed soil conditions (Data are combined across seasons).

\begin{tabular}{|c|c|c|c|c|c|c|c|c|c|}
\hline \multirow{2}{*}{$\begin{array}{l}\text { Ascorbic acid } \\
\left(\mathrm{mgL}^{-1}\right)\end{array}$} & $0 \mathrm{Ca}^{+2}$ & $+\mathrm{Ca}^{+2}$ & Mean B & $0 \mathrm{Ca}^{+2}$ & $+\mathrm{Ca}^{+2}$ & Mean B & $0 \mathrm{Ca}^{+2}$ & $+\mathrm{Ca}^{+2}$ & Mean B \\
\hline & \multicolumn{3}{|c|}{ Iron (ppm) } & \multicolumn{3}{|c|}{ Manganese (ppm) } & \multicolumn{3}{|c|}{ Zinc (ppm) } \\
\hline $\mathbf{0}$ & 416 & 464 & 440 & 246 & 274 & 260 & 166 & 188 & 177 \\
\hline 200 & 437 & 495 & 466 & 263 & 292 & 278 & 181 & 204 & 193 \\
\hline 400 & 466 & 535 & 501 & 285 & 315 & 300 & 199 & 229 & 214 \\
\hline 600 & 459 & 527 & 493 & 280 & 311 & 296 & 198 & 225 & 212 \\
\hline Mean A & 445 & 505 & & 269 & 298 & & 186 & 212 & \\
\hline 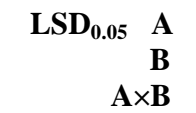 & & $\begin{array}{l}36 \\
23 \\
48\end{array}$ & & & $\begin{array}{l}26 \\
17 \\
34\end{array}$ & & & $\begin{array}{l}22 \\
15 \\
30\end{array}$ & \\
\hline
\end{tabular}

69.3, 13.9, 15.4 and $20.9 \%$ for N, P, K, Ca, Ca/Na ratio, $\mathrm{Fe}, \mathrm{Mn}$ and $\mathrm{Zn}$, respectively. Contrary, $\mathrm{Na}$ reduced up to $28.4 \%$. Ascorbic acid increased the tolerance of cotton plants, especially at the rate of $400 \mathrm{mgL}^{-1}$ under studied soil salinity. This reflected on improving vegetative growth traits (Table 3), photosynthetic pigments (Table 4), photosynthates among them endogenous ascorbic acid (Table 5) and seed cotton yield (Table 9), surely reflected also on stimulating the nutritional status of plants. These results are supported by the results of Ahmed and Abd El-Hameed (2004), shoots with $400 \mathrm{mgL}^{-1}$ ascorbic acid solution. This treatment scored 15.7, 30.6, 19.9, 28.0, 60.8, 15.3, 15.0 and $21.8 \%$ for $\mathrm{N}, \mathrm{P}, \mathrm{K}, \mathrm{Ca}, \mathrm{Ca} / \mathrm{Na}$ ratio, $\mathrm{Fe}$, $\mathrm{Mn}$ and $\mathrm{Zn}$, respectively compared with the treatment of $\mathrm{Ca}^{++}$past treated seeds under tap water spray. Contrary, $\mathrm{Na}$ decreased down to 20.0\%. In addition, the treatment of $\mathrm{Ca}^{++}$past treated seeds under $400 \mathrm{mg} \mathrm{L}^{-1}$ ascorbic acid granted increases at 48.9, 95.8, 53.7, 52.2, 228.0, $28.6,28.0$ and $38.0 \%$ for the same parameters, respectively as compared with the treatment of the interaction of calcium paste untreated-seeds under

Table (9): Influence of calcium paste and ascorbic acid on seed cotton yield and lint\% of cotton plants under saline reclaimed soil conditions (Data are combined across seasons).

\begin{tabular}{|c|c|c|c|c|c|c|c|c|c|}
\hline \multirow{2}{*}{$\begin{array}{l}\text { Ascorbic acid } \\
\quad\left(\mathrm{mgL}^{-1}\right)\end{array}$} & $\mathrm{O} \mathrm{Ca}^{+2}$ & $+\mathrm{Ca}^{+2}$ & Mean B & $\mathrm{O} \mathrm{Ca}^{+2}$ & $+\mathrm{Ca}^{+2}$ & Mean B & $\mathrm{O} \mathrm{Ca}^{+2}$ & $+\mathrm{Ca}^{+2}$ & Mean B \\
\hline & \multicolumn{3}{|c|}{$\begin{array}{c}\text { Seed cotton yield } \\
\text { hill }^{-1}(\mathrm{~g})\end{array}$} & \multicolumn{3}{|c|}{$\begin{array}{l}\text { Seed cotton yield } \\
\text { feddan }^{-1}(\text { kentar })\end{array}$} & \multicolumn{3}{|c|}{$\begin{array}{c}\text { Lint } \\
(\% \text { seed cotton })\end{array}$} \\
\hline (0 & 13.7 & 42.2 & 28.0 & 2.62 & 8.01 & 5.32 & 32.2 & 36.0 & 34.1 \\
\hline 200 & 19.4 & 48.7 & 34.1 & 3.68 & 9.25 & 6.47 & 32.7 & 36.2 & 34.5 \\
\hline 400 & 40.1 & 58.2 & 49.2 & 7.66 & 11.04 & 9.35 & 34.0 & 37.4 & 35.7 \\
\hline 600 & 39.4 & 57.1 & 48.3 & 7.48 & 10.83 & 9.16 & 33.5 & 37.0 & 35.3 \\
\hline Mean A & 28.2 & 51.6 & & 5.36 & 9.78 & & 33.1 & 36.7 & \\
\hline $\begin{array}{r}\mathbf{L S D}_{0.05} \\
\mathbf{B} \\
\mathbf{A} \times \mathbf{B}\end{array}$ & & $\begin{array}{l}4.3 \\
3.0 \\
6.4\end{array}$ & & & $\begin{array}{l}0.80 \\
0.54 \\
1.18\end{array}$ & & & $\begin{array}{l}3.1 \\
\text { NS } \\
4.6\end{array}$ & \\
\hline
\end{tabular}

Rady and El-Sawah (2009) who reported that the effect of antioxidants, especially ascorbic acid on producing healthy plants leads to enhancing the plants to have a great ability for uptake of elements. Moreover, Gonzalez-Reyes et al. (1994) concluded that ascorbate free radical caused hyper polarization of plasma membranes, and this energization could then facilitate transport processes across such membranes. Most of the previous results are consistent with those of Ali (2000), Rady and El-Sawah (2009).

The data presented in Tables (6-8) show that the best treatment in which plant leaf collected the highest amounts of nutrients, (except with the reverse regarding $\mathrm{Na}$,) was covering the seeds with calcium paste interacted with spraying plant tap water, whereas Na reduced up to $53.3 \%$. The increments obtained from the above mentioned best treatment may be explained with the increasing value of $\mathrm{Ca} / \mathrm{Na}$ ratio which reveal that $\mathrm{Ca}^{++}$behave when takes out $\mathrm{Na}^{+}$at significant amounts from rhizosphere and consequently from plant leaf. (Table 7) reflected on increasing nutrients in plants. Besides, the water imbibing properties of wheat bran fibers (Table 2), and their ability to absorb water and/or organic compound (Mongeau and Brassard, 1982) support the rhizophere by water to face drought and salinity. The acidity of humic acid facilitate more solubility and absorption of nutrients. As for ascorbic acid, Wise and Naylor (1987) stated that antioxidants such as ascorbate, glutathione and $\alpha$-tocopherol 
are directly correlated with the ability to defend plant cells against oxidative damage resulting from salinity stress and consequently producing healthy plants having a great ability for nutrients uptake.

\subsection{Seed cotton yield}

Combined data in Table (9) indicate that seed cotton yield hill $^{-1}$ and feddan ${ }^{-1}$ as well as lint $\%$ were significantly increased by $83.0,82.5$ and $10.9 \%$ as a result of covering the seeds before sowing with calcium paste, respectively as compared with calcium paste untreated seeds. The improvement in seed cotton yield and lint \% may be due to the existence of $\mathrm{Ca}^{++}$to take the place of $\mathrm{Na}^{+}$in the rhizosphere and in plant leaf as shown in Table (7). This may be positively reflected on plant growth (Table 3) and leaf photosynthetic pigments (Table 4) as well as macro- and microelements (Tables 6-8) and other components, such as total soluble sugars and free proline (Table 5) as osmotic substances and consequently the increase in seed cotton yield and lint \%. Moreover, the better water retention capacity of wheat bran (Table 2) and humic acids partially capable to retain water and nutrients (Osman and Ewees, 2008) in the rhizosphere led to overcoming the harmful effect of salinity. Raviv (1998) stated that humic acids may exert direct enzymatic or hormonal effects on plant growth and yield.

The sub-main treatment of ascorbic acid foliar application at the rate of $400 \mathrm{mgL}^{-1}$ gave the highest increases for seed cotton yield hill ${ }^{-1}$ and feddan ${ }^{-1}$ as compared with the other ascorbic acid rates. These increases were significant comparing with the rates of 0 (control) and $200 \mathrm{mgL}^{-1}$ whereas, they were insignificant as compared to $600 \mathrm{mgL}^{-1}$.Estimation of Lint $\%$ revealed insignificant values among all ascorbic acid rates. The increases in seed cotton yield hill $^{-1}$ and feddan $^{-1}$ scored at $400 \mathrm{mgL}^{-1}$ ascorbic acid solution were 75.7 and $75.8 \%$, respectively as compared to the treatment of zero rate ascorbic acid. The improving effect of ascorbic acid on seed cotton yield was mainly attributed to its positive action on enhancing growth traits (Table 3 ), photosynthetic pigments of plant leaf (Table 4), cellular solutes i.e. total soluble sugars and free proline (Table 5) for sustenance of cells turgor leading to maintenance of metabolic activities in plants and plant nutritional status (Tables 6-8). In this respect, Al-Qubaie (2002) stated that ascorbic acid as an antioxidant compound has an auxinic action and also synergistic effect on the biosynthesis of carbohydrates and controlling the incidence of most fungi on plants. This stimulates them and reflects on seed cotton yield. Besides, the induced effect of ascorbic acid as one of vitamins on growth and yield may be due to that vitamins are recognized to be coenzymes involved in specific biochemical reactions in plants such as oxidative and non-oxidative decarboxylations (Robinson, 1973). The results regarding the beneficial effect of ascorbic acid on seed cotton yield are confirmed with those reported by Rady and El-Sawah (2009).

The interaction between treated or untreated seeds with calcium paste and ascorbic acid foliar application at various rates, had a significant effect on seed cotton yield hill and feddan and in significant effect on lint \% Table (9). The highest values were obtained with the application of 400 $\mathrm{mgL}^{-1}$ ascorbic acid. This treatment increased seed cotton yield / hill and feddan as well as lint \% by $3.9 \%$, respectively by $324.8,321.4$ and $16.1 \%$, respectively as compared to zero $\mathrm{mgL}^{-1}$ ascorbic acid under untreated seeds with calcium paste. This favorable yielding may be due to the positive combined effect of calcium, wheat bran and humic acid. The former has an antagonistic effect to the harmful effects of $\mathrm{Na}^{+}$, the second has a high percentage of fibers (Table 2) having several physiological effects, depending upon the physical and chemical properties among them, the ability of fibers to retain water and to bind organic compounds (Schneeman, 1986) deluting salinity concentration and saving acidity effect with the latter; humic acid in rizhosphere and consequently more solubility and absorption of nutrients by plant roots.

In conclusion, within the experimental conditions studied, it has been concluded that the present results gave an evidence to the role of the calcium paste components; $\mathrm{Ca}^{++}$has an effective role in $\mathrm{Na}^{+}$driving out from saline rhizosphere, wheat bran has a high water holding capacity due to its high contents of fibers to save more water in the rhizosphere against salinity and humic acid which increases useful soil microorganisms for plants, function as auxins affecting plant metabolism in a positive manner and acts as chelating agent through hydroxyls and carboxyls as active groups for micronutrients and water molecules. Thus, minimizes the loss of nutrients by leaching. Besides, it is considered as a storehouse with easily mobile or available to uptake by plant roots, and in turn is positively reflected on growth and yield through overcoming the harmful effects of soil salinity. In addition, the role of ascorbic acid as an antioxidant, especially at the concentration 
of $400 \mathrm{mg} \mathrm{L}^{-1}$, in inducing salinity tolerance of cotton plants cultivated in salt-affected reclaimed soils.

It has been recommended that cultivation of cotton crop can be accomplished in saline reclaimed soils possess salinity level up to 7000 ppm with using some assistant factors. They are covering the seeds before sowing with calcium paste (mixture consists of calcium nitrate, humic acid and wheat bran at the ratio of $1: 1: 3$ by weight, respectively). Then, spraying the produced plants with ascorbic acid at the rate of $400 \mathrm{mgL}^{-1}$ three times at 40, 60 and 80 days after sowing.

\section{REFERENCES}

Abbas M.A., Younis M.E. and Shukry W.M.(1991). Plant growth, metabolism and adaptation in relation to stress conditions. III. Effect of salinity on the internal solute concentrations in Phaseolus vulgaris. J. Plant Physiol., 138: 722-729.

Abdel-Naby A., El-Beltagy M.S., Abou-Hadid A.F., Helmy Y.I. and El-Abd S.O. (2001). Effect of salinity stress modified by calcium application on potato plants. Egypt. J. Hort., 28(4): 519-530.

Ahmed F.F. and Abd El-Hameed H.M. (2004). Influence of some antioxidants on growth, vine nutritional status, yield and quality of berries in banaty grapevines. Assiut J. Agric. Sci., 35(4): 131- 140.

Ahmed F.F., Darwish O.H., Gobara A.A. and Ali A.H. (1998). Growth, nutritional status and productivity of Flame seedless grapevine as influenced by the application of citrine and ascobine. Crops Sci., Soc. America, p. 252.

Al-Qubaie A.I. (2002). Response of Ficus nitida L. seedlings to the application of some antioxidants under soil salinity conditions. Minia J. Agric. Res. \& Dev., 22 (3): 235254.

Ali A.H. (2000). Response of Flame seedless grapevines to spraying with ascorbic acid and boron. Minia J. Agric. Res. \& Dev., 20 (1): $159-174$.

A.O.A.C. (1995). Association of Official Analytical Chemists. Official Methods of Analysis. The Fifteenth Ed., Washington, D. C., USA.

Arnon D.I. (1949). Copper enzymes in isolated chloroplasts. Polyphenol-oxidase in Beta vulgaris L. Plant Physiol., 24: 1-5.

Bates L.S., Waldren R.P. and Teare I.D.(1973). Rapid determination of free proline for water stress studies. Plant and Soil, 39: 205207.

Chapman H.D. and Pratt P.F. (1961). Methods of Analysis for Soil. Plants and Water, Univ. Calif., D.V., Agric. Sci., USA.

Cordoba-Pedregosa M.C., Gonzalez-Reyes J.A., Sandillas M.S., Navas P. and Cordoba F. (1996). Role of apoplastic and cell-wall peroxidases on the stimulation of root elongation by ascorbate. Plant Phyiol., 112: 1119- 1125.

Cramer G.R., Lauchli A. and Polito V.S.(1985). Displacement of $\mathrm{Ca}^{2+}$ by $\mathrm{Na}^{+}$from the plasmalemma of root cell. Plant Phyiol., 79: 207.

Dubois M.F., Gilles K.A., Hamiton J.K., Robers P.A. and Smith F. (1956). Colorimetric methods for determination of sugars and related substances. Anal. Chem., 28: 350354.

Elade Y. (1992). The use of antioxidants to control gray mould (Botrytis cineria) and white mould (Sclerotinia sclerotiorum) in various crops. Plant Pathol., 141: 417- 426.

Ella M.K.A. and Shalaby E.E.(1993). Cotton response to salinity and different potassium/sodium ratio in irrigation water.J.Agron. Crop Sci. 170:25-31.

El-Saidi M.T. (1997). Salinity and its effect on growth, yield and some physiological processes of crop plants. In: Strategies for improving salt tolerance in higher plants. Jaiwal, P.K.; R.P. Singh and Anju Gulati (Eds.). Oxford and IBH Publishing Co. Pvt. Ltd. New Delhi, Calcutta Enfield (USA), pp.111- 127.

Farago S. and Brunhold C. (1994). Regulation of thiol contents in maize roots by intermediates and effectors of glutathione synthesis. J. Plant Physiol., 144: 433- 437.

Foyer C.H. and Halliwell B. (1976). The presence of glutathione and glutathione reductase in chloroplasts: A proposed role in ascorbic acid metabolism. Planta, 157: 239- 244.

Foyer C.H., Furbank R.T., Harbinson J. and Horton P. (1990). The mechanism contributing to photosynthetic control of electron transport by carbon assimilation in leaf. Photosynth. Res., 25: 83-100.

Gomaze K.A. and Gomaze A.A. (1984). Statistical Procedures for Agricultural Research. $2^{\text {nd }}$ ed. John Wiley and Sons. Inc., New York, USA.

Gonzalez-Reyes J. A., Alcain F. J., Caler J. A., 
Serrano A., Cordoba F. and Navas P. (1994). Relationship between apoplastic ascorbate regeneration and stimulation of root growth in Allium cepa L. Plant Sci., 100: 23-29.

Gorham J. and Bridges J. (1997). Effect of calcium on growth and leaf ion concentrations of Gossypium hirsutum grown in saline hydroponic cultivars Plant Soil. 176:219-227.

Greenway H.R. and Munns R. (1980). Mechanisms of salt tolerance in nonhalophytes. Annu. Rev. Plant Physiol., 31: 149.

Gupta P.K., Nadgir A.L., Macarentias A.F. and Jagannathan V. (1980). Tissue culture of forest trees: Clonal multiplication of Tecoma grandis L. (treak) by tissue culture. Plant Sci. Letters, 17: 259-268.

Hafez A.R. and Mikkelsen D.S. (1981). Colorimetric determination of nitrogen for evaluating the nutritional status of rice. Commun. Soil Sci. and Plant Analysis, 12(1): 61-69.

Jackson M.L. (1967). Soil Chemical Analysis. Prentice-Hall of India Private Limited, New Delhi, pp.144-197 and 326- 338.

Jafri A.Z. and Ahmed R. (1995). Effect of soil salinity on leaf development, stomatol size and its distribution in cotton (Gossypium hirsutum L.) Pak. J. Bot. 27:297-303.

LaHaye P.A. and Epstein E. (1969). Salt tolerance by plants: enhancement with calcium. Science, 166: 395.

Leidi E.O. and Saize J.F.(1997).Is salinity tolerance related to $\mathrm{Na}^{+}$accumulation upland cotton (Gossypium hirsutum L.) seedling? Plant Soil. 190 (1): 67-75.

Maas E.V. (1986). Crop tolerance to saline soil and water. Proc. US. Pak. Biosaline Res. Workshop, Botany Dept., Karachi Univ., Pakistan, pp. 205- 219.

Marschner H. (1995). Mineral Nutrition of Higher Plants. The Second Ed. Academic Press Publ., New York (USA), pp. 559.

Mongeau R. and Brassard R. (1982). Insoluble dietary fiber from breakfast cereals and brans: bile salt binding and water holding capacity in relation to particle size. Cereal Chem., 59: 413.

Osman A.Sh. and Ewees M.S.A.(2008). The possible use of humic acid incorporated with drip irrigation system to alleviate the harmfull effects of saline water on tomato plants. Fayoum J. Agric. Res. \& Dev., 22(1): $52-70$

Page A.I., Miller R.H.and Keeny D.R.(1982). Methods of Soil Analysis. Part II. Chemical and Microbiological Methods. The Second Ed. Amer. Soc. Agron., Madison, Wisconsin, USA.

Piper C.S. (1947). "Soil and Plant Analysis". The University of Adelaide, Adelaide, UK.

Poovaiah B.W. and Reddy A.S.N. (1993). Calcium and signal transduction in plants. CRC Crit. Rev. Plant Sci., 12(3): 185.

Qadir M. and Shams M. (1997). Some agronomic and physiological aspects of salt tolerance in cotton (Gossypium hirsutum L.) J.Agron. Crop.Sci. 179:101-106.

Rady M.M. and. El-Sawah Nevein A (2009). Impact of some treatments on growth and yielding of pea plants grown under saline reclaimed soil conditions. J. Agric. Sci. Mansoura Univ., 34 (5): 4903-4926.

Rautenkranz A., Machler F., Martinoia E. and Oerti J.(1994). Transport of ascorbic and dehydroascorbic acids across protoplast and vacuole membranes isolated from barley (Hordeum vulgare L. cv. Gebrel) leaf. Plant Physiol., 106: 187- 193.

Raviv M. (1998). Horticultural uses of composted material. Acta Horticulturae, 469: 225-234.

Reinhardt D.H. and Roast T.L.(1995 a) . Developmental changes of cotton root primary tissues induced by salinity . Int.J.Plant Sci.,156:505-513.

Reinhardt D.H. and Roast T.L. (1995 b) .Salinity accelerates endodemal development and induces an exodermis in cotton seedling roots.Env.Expl.Bot.35:563-565.

Robinson F.A. (1973). Vitamins "Phytochemistry", Vol. III: 195-198, Lawrence P. Miller (Ed.), Van Nostrand Reinhold Co., New York.

Sayed R.A., Ibrahim M.A. and Solaiman B.M. (2007). Response of Valencia orange trees to foliar and soil application of humic acids under new reclaimed land conditions. The Third Conf. of Sustain. Agric. Dev., Fac. Agric., Fayoum Univ., 12-14 Nov.

Scandalios J.G. (1997). Molecular genetics of superoxide dismutases in plants. pp.527568. In: Scandalios, J.G. (ed.). Oxidative stress and the molecular biology of antioxidant defenses. Cold Spring Harbor Lab. Press, Plainview, N.Y. 
Schneeman B.O. (1986). Dietary fiber. Physical and chemical properties, methods of analysis, and physiological effects. Food Technol., 40: 104.

Shahidi F. and Wanasundara P.K.(1992). Phenolic-antioxidants. Crit. Rev. Food Sci. Nutr., 32: 67- 103.

Snedecor G. A. and Cochran A.D.(1980). Statistical Methods. The Seventh Ed., Iowa State Univ. Press, Ames, Iowa, USA.
Wise R.R. and Naylor A.W.(1987). The peroxidative destruction of lipids during chilling injury to photosynthesis and ultrastructure. Plant Physiol., 83: 272- 277.

Zhang X. and Schmidt R.E. (2000). Hormonecontaining products impact on antioxidant status of tall fescue and creeping bentgrass subjected to drought. Crop Sci., 40: 13441349.

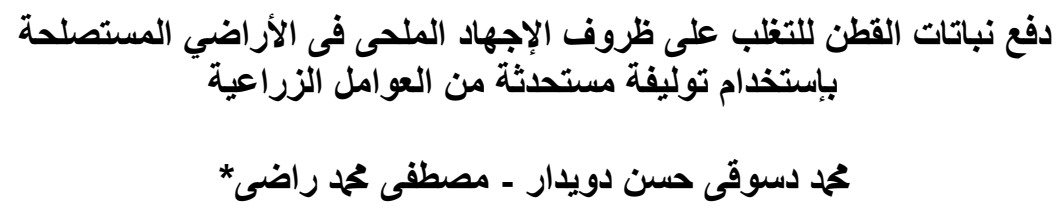

قسم المحاصيل ـ * قسم النبات الزراعى- كلية الزراعةـ جامعة الفيوم

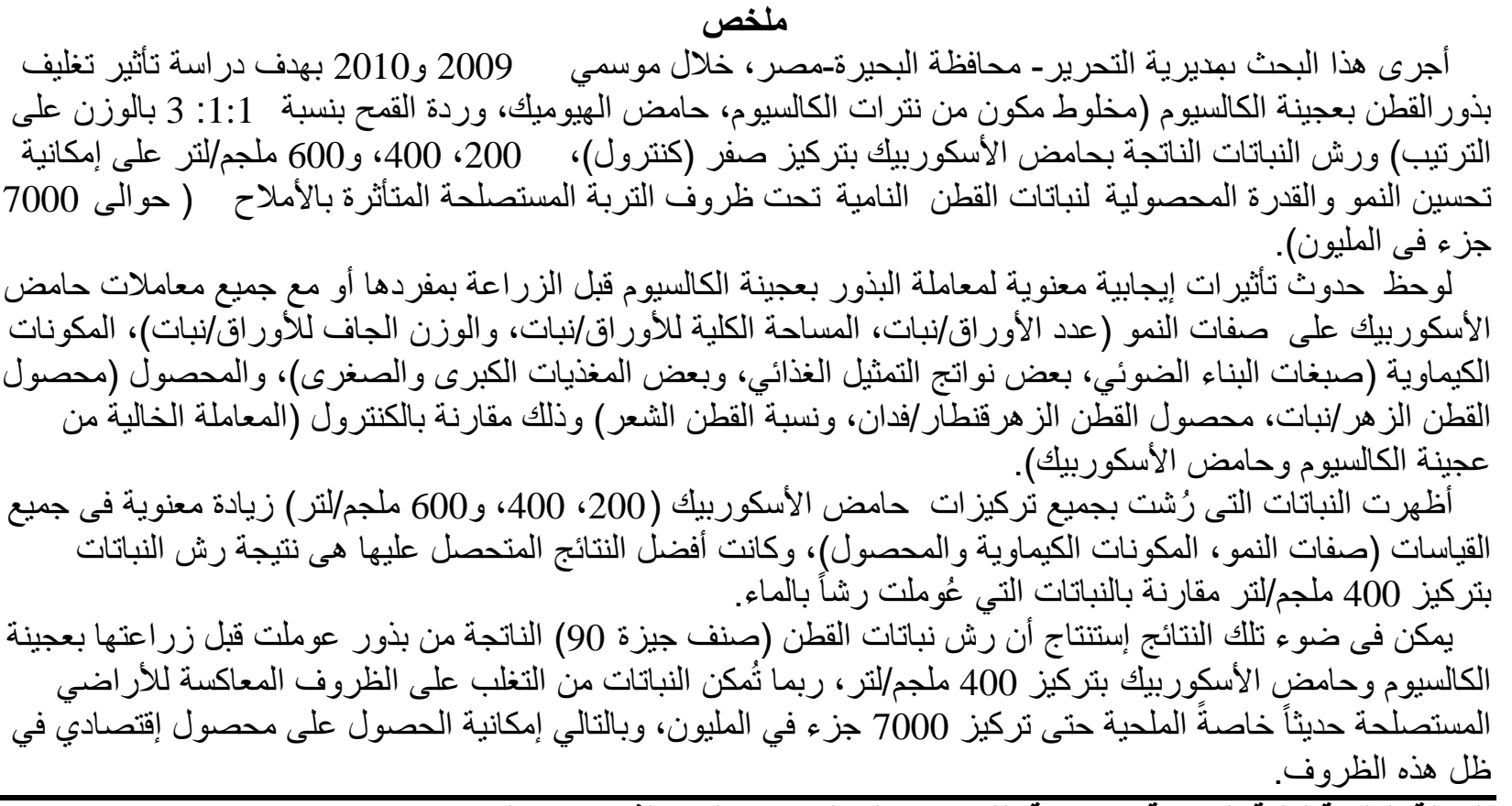

المجلة العلمية لكلية الزراعة - جامعة القاهرة - المجلا (62) العدد الثاني ( إبريل 2011):161-172. 